\title{
The Penal Condition in a Fixed-Term Employment Contract in Accordance with the Jordanian Labor Law and the Provisions of the Jordanian Court of Cassation
}

\author{
Ibrahim Saleh Al-Sarayra ${ }^{1} \&$ Alaa Mohammed Al-Fawair ${ }^{2}$ \\ ${ }^{1}$ Department of Comparative Law, University of Islamic International Sciences, Amman, Jordan \\ ${ }^{2}$ Faculty of Law, Jerash University, Jerash, Jordan \\ Correspondence: Ibrahim Saleh Al-Sarayra. E-mail: dr.ibraheimsarairah@yahoo.com
}

Received: May 15, 2018 Accepted: June 16, $2018 \quad$ Online Published: July 27, 2018

doi:10.5539/ass.v14n8p61 URL: https://doi.org/10.5539/ass.v14n8p61

\begin{abstract}
The employer shall enter into a penal condition such as an agreement compensation in fixed-term employment contracts, so that the worker shall not leave the work without any of the cases permitted by section 29 of the Jordanian Labor Law No. 8 of 1996 and its amendments.

The Jordanian legislator dealt with the case of leaving the worker for a fixed term contract in article 26 (b), which stipulates that the employer is entitled to compensation equivalent to half a month's wages for each month of the remaining period, provided that the employer proves that he was harmed, But not exceeding that amount.

By applying the penalty clause in fixed-term employment contracts, an owner has been able to analyze the evidence of the damage and the amount of the compensation is negligible.

We concluded by concluding with the conclusions and recommendations, the most important of which is that the penal clause in fixed-term employment contracts is contrary to the general protective regime of workers' rights.
\end{abstract}

Keywords: penal condition, term contract, compensation, damage

\section{Introduction}

The Jordanian legislator has provided for special rules in the Labor Law which are characterized by realism. Thus, we observe that the Jordanian legislator has dedicated special provisions for many issues; such issues include compensation of the worker in a fixed-term employment contract who leaves work illegally.

The Jordanian legislator has also provided the provisions of labor law with special consideration based on the restoration of balance between the parties of the contractual relationship (employer and workers), as he made the provisions of this law as binding and cannot be breached, particularly when such provisions are in favor of the worker.

The contract of employment, like other contracts, is subject to the general provisions stipulated in the Civil Code relating to the contract as a source of obligation. These provisions include the possibility of prior agreement on compensation in the event one of the parties to the contract has breached its provisions which is so-called penal condition.

\subsection{Objective of the Study}

The objective of this study is to determine the appropriateness of the penalty condition in the fixed term contract, especially since the nature of the penal condition contradicts the idea of the protection offered by the labor law which stipulates the minimum rights granted to the worker in case penal condition is not in worker's favor.

\subsection{Problem of the Study}

The problem of the study lies in determining the fate of the penal condition in the fixed term contract, especially since the legislator has estimated the compensation and set a maximum limit for such compensation. The amount of the compensation is marginally estimated, in addition to the presumption of damage in the penal condition.

\section{Methodology}

The researcher will apply the descriptive analytical approach through the description of the case and the analysis 
of juridical provisions.

\section{Study Proposal}

\subsection{Definition of Penal Condition}

The penal condition is considered as one of the most important conditions that can be mentioned in contracts because of the effect it entails. This condition must have been defined in the first section, and its characteristics should be defined in the second section, while its terms will be addressed in the third section, and finally, the fourth section will address its forms.

\subsubsection{Definition of Penal Condition}

The penal condition of penal condition according to scholars is "it is a prior agreement to estimate the compensation due to the creditor when the debtor fails to perform or delay. ${ }^{1}$

The penal condition is not independent, but is associated with an original obligation whether the source of this obligation is the contract or other source of obligation. It is not selective obligation because the creditor cannot choose between the original obligation and the penal condition. He has to claim the original obligation only, but if it is impossible to be implemented by the debtor, then the creditor claims the penal condition. He seeks compensation. Also, the penal condition is not an alternative obligation because the debtor cannot waive the original obligation as long as it is possible to be performed. ${ }^{2}$

Penal condition is usually intended by both parties to avoid the intervention of the judiciary and the intervention of the experts in the assessment of the compensation to which the creditor is entitled if the debtor breaches its obligation. The penal condition may be intended to modify the liability provisions by exemption or relief if the agreed is less than the expected damage, or to intensify liability if the amount is exaggerated. ${ }^{3}$

The penal condition is different from the down payment, since the penal condition is a contractual compensation for the damage caused to the creditor in case the debtor breaches its obligation, while the down payment is a sum of money paid by one of the parties of a contract to the other party at the time of the contract so that if the payer of down payment turns away from executing the contract, then he loses the amount of down payment he has paid, while the receiver of down payment pays the double of the amount of down payment if he turns away from executing the obligations of the contract.

The penal condition also differs from the preliminary fine in that the former is arbitral, in the sense that it is measured by the degree of damage that occurred, while the penal condition relates to compensation on the basis of the actual damage that is actually caused. ${ }^{4}$

\subsubsection{Features of Penal Condition}

The penal condition in contracts or in subsequent agreements provides a number of advantages to contractors, including ensuring that the obligation is fulfilled and the other party's rights are protected. The contractors also can avoid judicial intervention where they have full freedom to determine the type and amount of compensation, as the penal condition increases the contract's commitment strength and each contractor knows in advance that if he fails to fulfill his obligation, then he shall be obliged to pay the compensation provided in the condition. ${ }^{5}$

The importance of the existence of a penal condition lies in the fact that it makes the damage presumptive that the creditor is exempted from proving it and this is a proof valid to be inversely proved. The penal condition is also considered to be subject to estimation, and is therefore subject to review by the judiciary. ${ }^{6}$

It should be pointed out that the provisions of the penal condition are considered to be of the public order, where the agreement on the penal condition shall be considered as null and void if it includes an exemption or a reduction of liability in the case where the debtor has committed a fraud or a serious error. Article 358/2 of the Civil Code stipulates that: in any event the debtor remains liable for fraud or serious error "in addition to the inadmissibility of agreeing to exclude the authority of the court to modify the value of penal condition. ${ }^{7}$

\subsubsection{Terms of Penal Condition}

In order to fulfill the penal condition, the terms for compensation must be fulfilled, namely: loss and damage, causal relationship, and finally the notification when required. In the case of an error, the creditor shall prove it, unless the contractual obligation was intended by the debtor to fulfill an obligation to achieve a result, then the creditor must prove that it has not been achieved, and if he does so, then the error is assumed to be committed by the debtor and the latter should deny responsibility for establishing proof of existence of the foreign reason in order to avoid liability. ${ }^{8}$

The legislator has transferred the burden of proof from the creditor to the debtor, in the sense that the creditor has 
not to prove the damage, but the debtor had to prove the contrary, and that is the benefit the creditor has from the inclusion of penal condition in the contract in addition to the availability of causality between the error and causation relationship. ${ }^{9}$

Notification means notifying the debtor that the creditor is not cooperating to practice its right, so notification can be through the notary public, registered mail, or in any other way that achieves the intended purpose. ${ }^{10}$

It can be said that notification has a three-dimensional purpose. On the one hand, it is intended to inform the debtor that the creditor has a vested interest in the immediate implementation of the obligation; on the other, it gives the debtor a last chance to execute the contract; and that the debtor has the right to formally prove that the debtor has not fulfilled its obligation which enables the creditor to adhere to such enforcement. ${ }^{11}$

With regard to these conditions, one of the decisions of the Court of Cassation No. 212/2017 stated that: " Consensual Compensation (penal condition) is only entitled if the conditions of compensation are met general, namely, error, damage, causal relationship and notification in accordance with the provisions of Articles 361, 364 ) of the Civil Code, and where the documents of the case were free of any notification submitted by the appellee to the appellants ,and therefore, the condition of the entitlement of the penal condition is not available in the case of appeal and this case. ${ }^{12}$

\subsubsection{Forms of Penal Condition}

The penal condition is usually determined by a sum of money, but there is nothing to prevent such amount is to be returned as long as the parties have agreed to do so which is likely to be in kind, a good example includes that when ${ }^{13}$ computer systems companies make a condition that if an original software copy is not paid, then it will be deactivated.

\subsection{The Effect of Penal Condition in Fixed Term Employment Contract}

If the penal condition is included in the contract of employment and other contracts, it is not considered absolutely, but there is a judiciary that limits or amends it, but can this condition be considered in the fixed term contract.

\subsubsection{Judge's Power to Amend the Penal Condition}

Article 364 of the Civil Code stipulates that:

1 - The contractors may specify in advance the value of the guarantee by including it in the contract or in a subsequent agreement, subject to the provisions of the law.

2. In any case, the Court may, at the request of either party, amend this Agreement so as to render the estimation equal to the damage and any agreement contrary to that shall be null and void. "

The Court of Cassation in its decision No. 1144/2016, ruled that: "The jurisprudence has determined that the parties to the contract have the right to determine the value of the guarantee (penal condition) in advance if one of them breaches the terms of the contract concluded between them, and the competent court has discretion to modify the value of the penal condition in accordance with the provisions of Article 364 of the Civil Code". 14

It is clear from the legal text of the Article and the decision of the Court of Cassation that the court has such authority, but the Jordanian legislator did not specify cases of reducing the penal condition or increasing it in the same way as the Lebanese legislation.

However, we can refer to these cases, which are mentioned in the jurisprudence as follows:

First: Reduction of the value of the penal condition

Originally, if the terms of the penal condition are met then the judge has the power to determine the agreed amount exactly, but it is excluded that the judge has the power to reduce such estimation in all cases where it is clear that estimation exceeds the damage suffered by the damaged party, but the legislator prevented the judge from intervening to reduce this estimate only at the request of (one of the parties). ${ }^{15}$

These cases include:

1. If the debtor proves that the original obligation has been partially implemented, the objective here is clear, because if the penal condition is conditional on the debtor's failure to perform its full obligation, fairness requires that the full amount agreed upon shall not be paid in full if the obligation is partially implemented.

2. If the estimation of compensation is greatly exaggerated, and the debtor bears proof thereof, where the exaggerated penal condition is intended to conceal These include:

1. If the debtor proves that the original obligation has been partially implemented, the objective here is clear, 
because if the penalty condition is conditional on the debtor's failure to perform its full obligation, justice requires that the full amount agreed upon if partially implemented. ${ }^{16}$

2. If the estimate of compensation is greatly exaggerated, and the debtor bears proof thereof, where the exaggerated penalty clause is intended to conceal usurious interest that must be reduced to the legal limit. ${ }^{17}$

Second: Increase of penal condition amount value

If the agreed compensation is less than the damage, it shall be subject to the provisions of the requirement of mitigation or exemption from liability. The judge shall apply the penal condition agreed upon in this case even if it is less than the actual damage; at the will of the contractors who intended to mitigate the liability, but the Jurisdiction of the judge becomes clear in cases where the error is not ordinary, but gross or fraudulent, then, the condition is null and void and the judge assesses the compensation in accordance with the damage suffered by the creditor. ${ }^{18}$

One of the most important circumstances to be taken into account in all cases of unlawful termination of a fixed-term contract is the possibility of finding another worker of the same qualification as the worker who ends the contract unlawfully. ${ }^{19}$

\subsubsection{The Possibility of Considering the Penal Condition in Fixed Term Employment Contract}

Originally, the duration of employment contract is not limited for a certain period, where a limited contract is a contract where the parties agree to terminate it at its date of expiry. ${ }^{20}$

Article 21 of the Labor Law provides for the cases of termination of employment contracts, namely:

(a) If the parties agree to terminate it.

(b) If the term of the employment contract has expired or the work itself has ended.

(c) If the worker dies or is incapacitated by a sickness or incapacity to work, and a medical report issued by the Medical Reference is submitted.

(d) If the worker reaches the age of old age pension provided for in the Social Security Law unless the parties agree otherwise.

Accordingly, if the contract is a fixed-term contract, the normal termination of the contract is the expiry of its term or the end of the work specified, without the need for prior notification by one party to the other. ${ }^{21}$

On the other hand, the legislator pointed out that termination of a fixed term contract by the worker is unlawful termination. Article 26 states: "a. If the employer terminated the fixed term employment contract before the expiry of its term or terminated by the worker for one of the reasons stated in Article (29) of this Law, the worker shall be entitled to deserve all the rights and benefits provided for in the contract and shall be entitled to the wages due until the end of the remaining period of the contract unless the termination of the employment contract is due to a discharge under Article 28 of this law.

b. If the termination of the fixed-term contract issued by the worker in cases other than those provided for in Article (29) of this law, the employer shall be entitled to claim the damage caused by such termination and the competent court shall determine such compensation, provided that a compensation paid by the worker shall not exceed half a month wage for each month of the remaining period of the contract. "

This means that the employer must prove the loss and damage that he suffered to be compensated against. Leaving of work by a worker is considered as an adverse act, and accordingly, the employer must prove the damage resulting from this act. If so, the maximum compensation must not exceed a half-month wage for each month of the remaining period of the contract. ${ }^{22}$

This means that the judge may not issue a rule any compensation as if the employer found a suitable alternative worker immediately after the previous worker has been left the work, but the legislator has determined the maximum limit of the amount to be paid as a compensation to the employer. ${ }^{23}$

It is noted that Article $26 /$ (a) provided for compensation for the remaining period of the contract in addition to the entitlement of all other rights without reference to the damage, unlike the case with paragraph $26 / \mathrm{b}$ which refers to the loss and damage due to termination of the contract by the worker.

This means the different basis of compensation for each party due to the unlawful termination of the employment contract which is the occurrence of loss and damage suffered by the employer, but loss and damage should not necessarily occur and suffered by the worker to be compensated against

However, the Court of Cassation in its decision No. 515/2017, stated that: "In accordance with the provisions of 
Article 346 of the Civil Code, contractors may determine in advance the value of the warrantee "bond" provided for in the contract or through a subsequent agreement, and in any case, the Court may, at the request of one of the parties, amend such agreement to make the estimate equal to the damage. If such condition is met, it shall not be in breach of the Labor Law, as it has been agreed before the commencement of the work. This condition shall be according to Article (26) of the Labor Law, which must be taken into account in the award of compensation if the termination of a fixed-term contract is committed by the employee in cases other than those stipulated in Article (29) of the same law, in accordance with the resolution of the Court of Cassation no. (32/2017) $)^{24}$

Also, decision No. 273/2017 of the Court of Cassation which stated: "judiciary, since the decision of the General Assembly No. (32/2017), has stated that the breach of a worker's obligation causes damage to the employer which must be compensable as soon as the worker breaches its obligation and the employer may not obliged to prove such damage, but the worker has to prove the non-occurrence of such damage ; and also, judiciary has provided for that a fixed term employment contract shall remain unlimited even it is not subject to renewal for more than once in accordance with the resolution of the Court of Cassation no. $(2012 / 07) .^{25}$

However, the researchers disagree with the honorable Court of Cassation, since if the conditions of the contract are not in favor of the worker, they will be invalid, since these conditions are contrary to the provisions of the Labor Law. The law provides for the minimum worker's rights, thus, every condition that violates these rights is null and void and the reason for the invalidity of the penal condition in this case is to increase the obligation of the worker to pay what is over the scope of Article 26 / b so as to make this requirement contained in the contract contrary to the text of this article and pursuant to Article 4 of the Labor Law:

a) The law shall not affect any of the rights granted to the worker by any other law, contract, decision or agreement if any of them grants a right for the worker better than those set forth under the provisions of this law.

b) Any condition of a contract or agreement, whether concluded before or after this Act, whereby any worker waives any of the rights granted to him shall be null and void.

Accordingly, we must distinguish whether the penal condition is included in the individual employment contract, which includes rights and benefits for the worker which are better than the legal text or the text of the rules of procedure.

However, some scholars ${ }^{26}$ believes in the possibility of that the parties to the contract may determine in advance of compensation in the case of absolute premature termination of the contract. This agreement shall apply to the general rules of the penal condition. In the event of premature termination by the worker, the employer's compensation shall be estimated based on the loss and damage suffered by the employer based on the disturbance of the condition of the work.

However, the nature of the protective rules of the labor law, including the principle of the most favorable condition of the worker, which has a direct impact on the effectiveness of the penal condition, and after this condition has enjoyed the mandatory force, this force was contrary the "best condition of the worker" causing the violation of such rights granted to the workers by law.

\section{Conclusion}

Having finished this study entitled" The penal condition in a fixed-term employment contract" the current study has showed the following results:

1. The penal condition usually includes the agreement of the parties to the liability ceiling so that the breach of the contract will result in the payment of what is included in this condition, so that the amount of the compensation is estimated randomly.

2. The penal condition exempts the party who suffers loss and damage due to the unlawful termination of the work from proving the damage, although the legislator did not stipulate that the worker should suffer loss and damage in order to claim his rights in addition to the penal condition, but it provided for that the employer should suffer loss and damage due to the termination of the contract by the employer unlawfully ,and the worker should shoulder the burdens of proving the non-occurrence of such loss and damage.

3. The recent directions of the Court of Cassation to apply this condition and that the contract of employment is like other contracts, noting the availability of the terms of the agreement; the fault, the damage and the relationship of causality.

4. The consideration of the penal condition in fixed-term employment contracts is contrary to Article 26 (b) of the Jordanian Labor Law. 


\section{Recommendations}

1- We hope that our Jordanian judiciary, represented by the Court of Cassation, not to consider the penal condition in fixed-term employment contracts, so that this is not a justification for employers to pressure workers to accept this condition.

2 - We hope to apply the penal condition in the contracts of unlimited employment contracts in case the worker leaves work without the occurrence of any of the cases contained in Article (29), on the grounds that the value of compensation is not known by both parties.

\section{References}

Al-Adawi, J. (n. d.) Compliance Provisions. University House, Egypt.

Al-Far, A. Q. (2002). Provisions of Commitment. Dar Al-Thaqafa for Publishing and Distribution, Jordan.

Al-Maghrabi, J. (2018). Explanation of the provisions of the Labor Law. Dar Al-Thaqafa for Publishing and Distribution, Jordan.

Al-Nasiri, S. (2010). Labor Law - Comparative Study. Modern University Office, Oman.

Al-Sharqawi, J. (1983). The General Theory of Commitment (Book II, p. 2010).

Daradkeh, F. S. (1994). The Penal Condition in the Compensatory Compensation in Jordanian Civil Law Comparative Study (Master Thesis). Graduate School, University of Jordan.

El-Rab, H. M. J. (2013). Dar Al-Fikr Al-Jamei'e (p. 180). Egypt.

Hashim, H. R. (1990). Explanation of Jordanian Labor Law. No Publication House, Jordan.

Mahmoud, H. M. (1988). Labor Law - Individual Employment Contract. Dar al-Maarifah Al-Jamieyah, Egypt.

Shanab, A. A. K. A. (2010). Explanation of Labor Law. Dar Al-Thaqafa for Publishing and Distribution, Jordan.

Sorour, S. (1985). Summary of the General Provisions of Compliance in the Egyptian Civil Code (1st ed.).

Sultan, A. (1983). Provisions of Obligation. Dar al-Nahda al-Arabiya, Egypt.

www.qistas.com

\section{Notes}

Note 1. Dr. Jalal Al-Adawi, Provisions of Obligation, University House, Egypt, No Publication Year, p. 140, Anwar Sultan, Rules of Obligation, General Theory of Obligation: A Comparative Study between the Egyptian and Lebanese Laws, 1974, p. Al-Masri, 1st edition 1985, p. 168.

Note 2. Dr. Anwar Sultan, Provisions of Obligation, Dar al-Nahda al-Arabiya, Egypt, 1983, p. 70

Note 3. Dr. Jalal Al-Adawi, ibid,p. 144.

Note 4. Dr. Abd al-Qader al-Far, Provisions of Commitment, Dar Al-Thaqafa for Publishing and Distribution, Jordan, 2002, p 85.

Note 5. Fouad Saleh Daradkeh, The Penal Condition in the Compensatory Compensation in Jordanian Civil Law Comparative Study, Master Thesis, Graduate School, University of Jordan, 1994, p 96

Note 6. Dr. Abd al-Qader al-Far, ibid, $\mathrm{p} 86$.

Note 7. Fouad Saleh Daradkeh, ibid, p 292

Note 8. Dr. Anwar Sultan, ibid, p. 74

Note 9. Dr. Jalal Al-Adawi, ibid,p. 142.

Note 10. Dr. Abd al-Qader al-Far, ibid, p 81.

Note 11. Dr. Hosny Mohamed Jad El--Rab, The Consensual Compensation for Non-Compliance, Dar Al-Fikr Al-Jamei'e, Egypt, 2013, p. 180

Note 12. Resolution of the Discrimination of Rights (212/2017) Jordanian Court of Cassation, Qistas, 2017.

Note 13. Jamil Al-Sharqawi, The General Theory of Commitment, Book II, 1983, p.20

Note 14. Decision No. (1144/2016) Court of Cassation of Jordan, qistas, 2016 
Note 15. Fouad Saleh Daradkeh, ibid, p 364

Note 16. Dr.Anwar Sultan, ibid, p. 77

Note 17. Fouad Saleh Daradkeh, ibid, p 366

Note 18. Dr. Jalal Al-Adawi, ibid,p. 147.

Note 19. Dr. Hisham Refaat Hashim, Explanation of Jordanian Labor Law, No Publication House, Jordan, 1990, p. 319

Note 20. Dr. Hammam Mohamed Mahmoud, Labor Law - Individual Employment Contract, Dar al-Maarifah Al-Jamieyah, Egypt, 1988, p. 478

Note 21. Dr. Sulaiman Al-Nasiri, Labor Law - Comparative Study, Modern University Office, Amman, 2010, p. 140

Note 22. Dr. Jafar Al-Maghrabi, Explanation of the provisions of the Labor Law, Dar Al-Thaqafa for Publishing and Distribution, Jordan, 2018, p 190

Note 23. Dr. Ahmed Abdul Karim Abu Shanab, Explanation of the Labor Law, Dar Al-Thaqafa for Publishing and Distribution, Jordan, 2010, p 308.

Note 24. Resolution of the Court of Cassation no. (515/2017) ,Court of Cassation of Jordan, qistas, 2017 www.qistas.com

Note 25. Resolution of the Court of Cassation no. (273/2017) ,Court of Cassation of Jordan, qistas, 2017 www.qistas.com

Note 26. Dr. Hammam Mohamed Mahmoud, ibid, p. 485

\section{Copyrights}

Copyright for this article is retained by the author(s), with first publication rights granted to the journal.

This is an open-access article distributed under the terms and conditions of the Creative Commons Attribution license (http://creativecommons.org/licenses/by/4.0/). 